\title{
Sugar-Sweetened Beverages Consumption and Its Association with Body Mass Index among College Students Living in Dormitory
}

\author{
Sifa Aulia Wicaksari ${ }^{1}$, Dian Novita Chandra ${ }^{2}$, Helda Khusun ${ }^{3}$, Diana Sunardi ${ }^{4}$ \\ ${ }^{I}$ Department of Nutrition, Faculty of Medicine, Universitas Indonesia, Jakarta, Indonesia, \\ sifaauliawicaksari@gmail.com \\ ${ }^{2}$ Department of Nutrition, Faculty of Medicine, Universitas Indonesia - Dr. Cipto Mangunkusumo Hospital, \\ Jakarta, Indonesia, dian.chandra@ui.ac.id \\ ${ }^{3}$ South-East Asian Ministers of Education Organization - Regional Center for Food and Nutrition (SEAMEO \\ RECFON) - Pusat Kajian Gizi Regional (PKGR), Universitas Indonesia, Jakarta, Indonesia, \\ hkhusun@gmail.com \\ ${ }^{4}$ Department of Nutrition, Faculty of Medicine, Universitas Indonesia - Dr. Cipto Mangunkusumo Hospital, \\ Jakarta,Indonesia,diana_sunardi@yahoo.com
}




\title{
SUGAR-SWEETENED BEVERAGES CONSUMPTION AND ITS ASSOCIATION WITH BODY MASS INDEX AMONG COLLEGE STUDENTS LIVING IN DORMITORY
}

\begin{abstract}
The global prevalence of excess adiposity increases annually, including in Indonesia. High energy intake from sugar becomes a global concern since it causes weight gain, tooth decay, and non-communicable diseases. This cross-sectional study assessed the association between body mass index and sugar-sweetened beverage consumption among college students. The study was conducted in Universitas Indonesia, West Java, Indonesia, during March - June 2019. The respondents were 161 college students living in dormitory aged 19-21 years old. They were enrolled using convenience sampling. Anthropometric measurement was obtained to calculate body mass index. The 7-days fluid record was the tool for assessing sugar-sweetened beverage consumption. Data were analyzed using SPSS version 20. The median body mass index was $20.6(15.11-41.29)$ kg. $\mathrm{m}^{-2}$, and added sugar intake in beverage was $23.4(0-134.4)$ grams per day. $24.2 \%$ of respondents had excess adiposity status, and $11.8 \%$ of respondents consumed added sugar in beverages exceeding 50 grams a day. Most of the respondents had inadequate total energy intake and low physical activity levels. Adjusted to total energy intake, physical activity level, and gender; body mass index significantly associated with sugar-sweetened beverages consumption in added sugar intake ( $\mathrm{p}$-value $=0.048, \beta=1.810,95 \%$ CI $0.014-3.606, \mathrm{r}=0.229$, $\mathrm{R}$ square $=0.028$ ).
\end{abstract}

Keywords: Sugar-sweetened beverage, young adult, added sugar, overweight-obesity

\section{Introduction}

The prevalence of excessive adiposity due to the long-term effect of positive energy imbalance increases every year globally, including in Indonesia (Sahoo et al., 2015, WHO, 2017). World Organization Health (2016) reported in 2016 that $38.9 \%$ of adults in the world were suffering from obesity. In Indonesian adults aged 18 years, it has increased from $19.1 \%$ in 2007 to $35.4 \%$ in 2018 (Kementerian Kesehatan, 2018).

Young adulthood, a transition stage from adolescence to adulthood, is a vulnerable group of significant lifestyle changes since they leave home and go to university (Poobalan and Aucott, 2016, Lanoye et al., 2016). In United States (US), about 3 of 10 college students were overweight; it is similar to data in Southeast Asian countries (28.75\%) (Sparling, 2007, Anderson and Good, 2017, Peltzer et al., 2014). This condition is more worrying since excess adiposity in younger age tends to occur during adulthood and increases the burden of health problems such as poor academic performance, diabetes, hypertension, sleep apnea, mortality, and morbidity (Anderson and Good, 2017, Hanandita and Tampubolon, 2015, Harbuwono et al., 2018, Metwally et al., 2007, Sahoo et al., 2015, WHO, 2000). Its contribution to the rising of non-communicable diseases (NCDs) prevalence, such as ischemic heart disease (IHD) and stroke, which are the two leading causes of global death (WHO, 2016). 
Genetic, age, gender, physical activity, sleep duration, and dietary intake were found as risk factors of excess adiposity (Boričić et al., 2014, Nurwanti et al., 2018, WHO, 2015). One of its which becomes a global concern is high free sugar intake that excessed energy intakes; this leads to unhealthy diet, weight gain, diabetes, tooth decay, increased risk of NCDs, poorer cognitive function and performance (RISKESDAS, 2013, WHO, 2015, Wang et al., 2013, Anderson and Good, 2017). Sugar is one of the food components naturally occurring in the food and can be added during food/ beverage processing, preparation, or table (Johnson et al., 2009). Meanwhile, sugar contributes to the energy in a sugar-sweetened beverage (SSB) as $75.68 \%$, and consuming energy in liquid form may increase the TEI due to less satiety than solid form (Haning et al., 2016, WHO, 2015, Mattes, 1996).

WHO recommends calorie percentage from sugar not exceeding 10\%, and the Ministry of Health $(\mathrm{MoH})$ of Indonesia recommends sugar consumption should be less than 50 gr (4 spoons) a day (Kodyat, 2014, WHO, 2015). A previous study reports that 10.9\% of Indonesian adults aged more than 18 years consumed energy from free sugar in beverages exceeding the WHO recommendation (Guelinckx et al., 2015). However, some studies did not find the association between BMI and SSB consumption (Andersen et al., 2005; Bandini et al., 1999, Pengpid and Peltzer, 2017; Bouchard et al., 2010, Jensen et al., 2013). These inconsistencies might be resulted due to the limitation of the method for assessing SSB consumption, the lower level intake of SSB compared to other populations, did not include other possible variables related to BMI (e.g., energy intake and physical activity), the extended time required to assess usual intake, the required representative day for assessing usual intake (Jensen et al., 2013). Therefore, this study aimed to describe the BMI and SSB consumption among college students and to assess the association between sugar-sweetened beverages consumption with body mass index, adjusted to other factors.

\section{Material and Methods}

This study was part of a more extensive study by the Department of Nutrition Sciences, Faculty of Medicine, Universitas Indonesia entitled "The Association between Food and Beverage Intake with Nutritional and Hydration Status" to assess the association between food and beverage intake with nutritional and hydration status. The inclusion criteria consist of young adults aged 19-21 years old, students of Universitas Indonesia, living in the student dormitory, and Indonesian citizens. Respondents on weight loss programs supervised by a health professional or reducing sweet food and beverage consumption were excluded. The respondent who did not finish the study's procedure was considered as dropping out. Data collection was conducted in March-June 2019.

Respondents were enrolled by convenience sampling in the dormitory canteen (Figure 1). The determination of Universitas Indonesia by considering that its location in the urban area of West Java, near the capital city of Indonesia, may face an unhealthy lifestyle related to excess adiposity problem. The student dormitory of Universitas Indonesia was chosen purposively to obtain high compliance of data collection, especially for 7-days fluid records. 


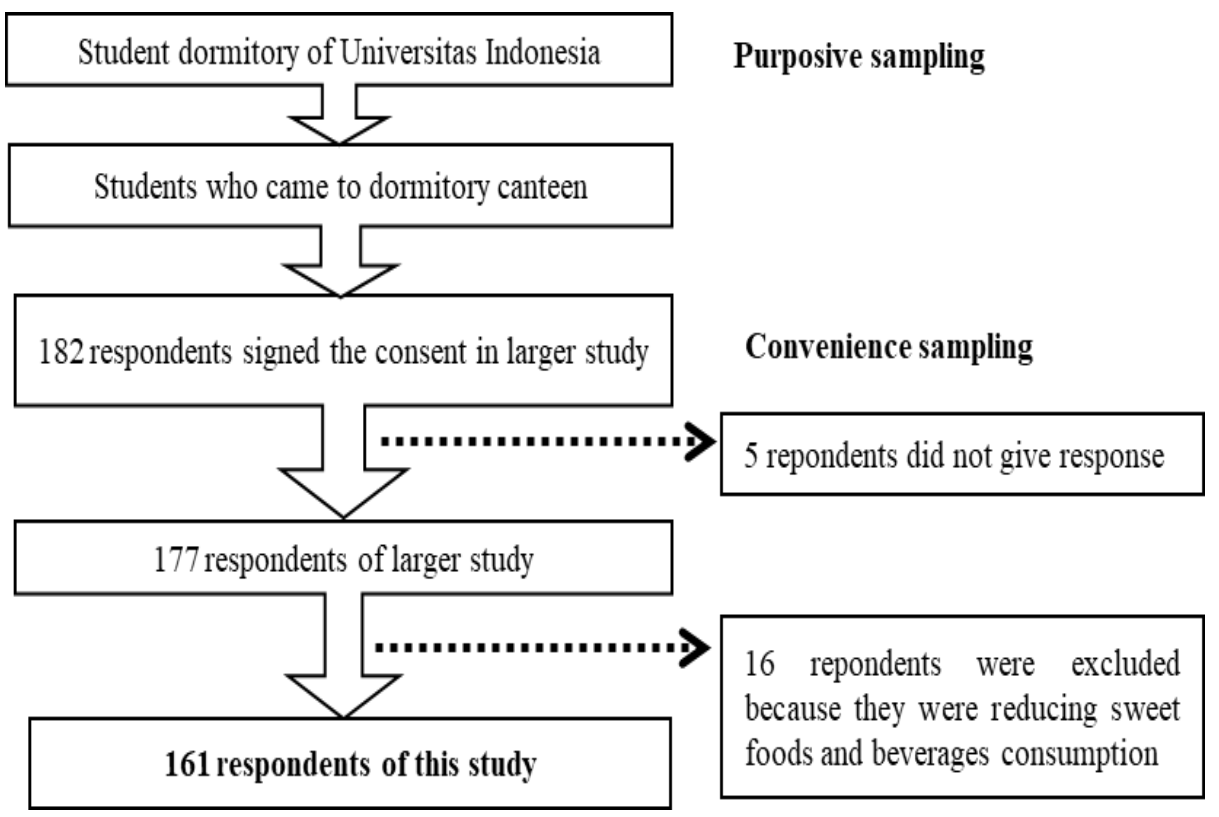

Figure 1 Sampling Procedure of Study

The minimum sample size needed in this study was 134 calculated from population proportion (P0) of $13.5 \%$, anticipated population proportion $(\mathrm{Pa})$ of $25 \%$, level of significance $\left(\mathrm{Z}_{1-\alpha / 2}\right) 95 \%$, power of the study $\left(Z_{1-\beta / 2}\right) 90 \%$ and design effect of 1.4 .182 respondents consented to participate, whereas 5 respondents did not complete the study. Of the 182 students who consented to participate, 16 respondents reducing sweet food and beverage were excluded. Therefore, 161 respondents participated in the study.

Body mass index as the outcome was calculated by dividing weight $(\mathrm{kg})$ by the height $(\mathrm{m}-2)$ square. The study used Seca ${ }^{\circledR} 876$ weighing scale and Shorrboard ${ }^{\circledR}$ measuring board to assess respondents' body weight and height. Weight and height measurements were done twice by a trained nutritionist, where the average of each measurement was used to calculate BMI. This study had been calibrated the instruments every before measurement and trained the enumerators to measure weight and height according to standard.

SSB as the independent variable was assessed using a 7-days fluid record. Bardosono et al. (2015) validated a 7-days fluid record to assess water and beverage intake in Indonesia and found a significant correlation compared to 24-hour recall ( $\mathrm{r}=0.333, \mathrm{p}<0.001)$ (Bardosono et al., 2015). The respondent self-administered this tool for 7-consecutive days-trained enumerator administered and explained to the respondent how to record the fluid and beverage. Daily face-to-face follow-up is done to minimize the respondents' copying of the data from the previous day to the next day. Guelinck et al. (2015) used this tool for evaluating fluid and beverage consumption across 13 countries compared to WHO recommendation (Guelinckx et al., 2015). Other potential factors such as sociodemographic status, energy intake, and physical activity were assessed using a structured questionnaire, 2-non-consecutive days 24-hours recalls, and Short International Physical Activity Level (IPAQ). Epidata 3.1, Microsoft Excel 2010, and Nutrisurvey 2004 were used for data management before analyzing with SPSS Version 20. Statistical analyses used in this study are the 
Spearman test, Mann-Whitney test, and multiple linear regression. Data is considered as significant if p-value $<0.05$.

\section{Results}

As seen in Table 1, the median BMI of college students was $20.6(15.11-41.29) \mathrm{kg} \cdot \mathrm{m}-2$. There were $57.2 \%$ of respondents with normal BMI, while the double burden of malnutrition did exist; overweight and underweight rates were $24.2 \%$ and $18.6 \%$, respectively. Median total fluid intake (TFI) was 1842 (721.9-4502.9) $\mathrm{ml}^{\text {.day }}{ }^{-1} ; 1556.2 \pm 657.9 \mathrm{ml}^{\text {.day }}{ }^{-1}$ from plain water and $217.4(0-$ 1580.6) ml.day $^{-1}$ from SSB. The highest SSB intake was derived from sugar-sweetened milk-based and tea drinks (66.5\% of respondents), followed by sugar-sweetened coffee drinks (38.5\%), and the lowest one was electrolyte drinks (8.1\%).

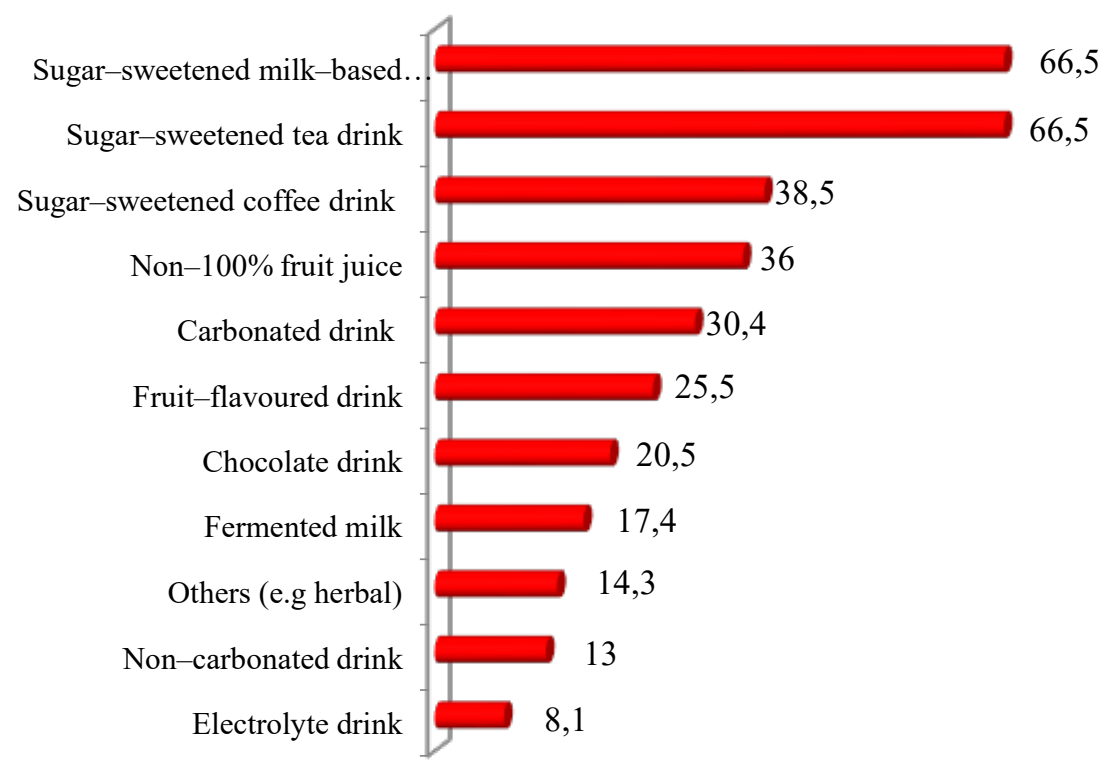

Figure 2 Sugar-sweetened beverages consumption stratified by type of SSB

Respondents consumed added sugar in SSB at 23.4 grams or equal to 2 tablespoons per day. Its contribution to energy intake was $126 \mathrm{kcal} /$ day or about $7.5 \%$ of the total energy intake (TEI). $11.8 \%$ of the college students consume added sugar exceeding the Indonesian Dietary Guideline 2014, or equally $36.6 \%$ of them consuming more calories than the WHO recommendation from fluid intake.

Bivariate analysis showed no correlations between BMI and SSB consumption (shown in Table 2). In contrast, further analysis of added sugar in SSB was considered to be continued in multiple analysis in Table 3 shows significant association with BMI $(r=0.229, p=0.048$, adj $\beta=1.1810,95 \%$ CI $0.014-$ 3.606). The college students who added sugar in SSB more than 50 g.day $^{-1}$ significantly increased BMI by $1.810 \mathrm{~kg} . \mathrm{m}^{-2}$ than those who consumed less than 50 g.day ${ }^{-1}$. Gender factor also showed significant association with BMI ( $\mathrm{p}=0.039$, adj $\beta=1.263,95 \%$ CI $0.067-2.459)$. 


\section{Discussion}

The body mass index of respondents was similar to reanalysis National Basic Health Research/ Riskesdas data which found that the mean BMI of Indonesian adult people aged $\geq 15$ years old was $22.05 \mathrm{~kg} \cdot \mathrm{m}^{-2}$ (Hanandita and Tampubolon, 2015). Based on the prevalence of excess adiposity and underweight, those prevalence were higher than the 2015 data that was $17.9 \%$ and $14.4 \%$, respectively (Hanandita and Tampubolon, 2015). This was possible due to different cut-offs for categorizing the BMI; this study used the Asian Pacific population cut-off, while the previous study used the global population cut-off.

The median body mass index tends to be normal. It is explained by the energy intake and physical activity level data, which shows most respondents had inadequate energy intake compared to RDA and low physical activity levels. The prevalence of respondents who had low physical activity levels doubled the national figure in 2018 (33.5\%) (Badan Penelitian dan Pengembangan Kesehatan, 2018). According to aged stratification, the national prevalence of people aged 15-24 years who had low PAL was between 32.6 - 50.2\% (Badan Penelitian dan Pengembangan Kesehatan, 2018).

The median BMI in this study was normal weight. Meanwhile, this study found $24.2 \%$ of respondents had excess adiposity (Hanandita and Tampubolon, 2015). Hanindita and Tampubolon's study in 2015 explained that as people getting older, they tend to have higher BMI. If the individual is overweight at the age of $15-24$ years old, they have an odds ratio of being overweight or obesity increasing up to 4 times at $45-54$ years old (Hanandita and Tampubolon, 2015).

One of the risk factors related to BMI is excessive sugar consumption. The Ministry of Health of Indonesia restricts daily sugar intake to less than 50 grams (Kodyat, 2014). Sugar-sweetened beverages were found to have less nutrient content, quick time consumption and contributed to overweight and obesity by excessing caloric intake (Sahoo et al., 2015). Compared to solid form, liquid form intake resulted in postprandial hunger, less fullness, quicker gastric emptying, reduced secretion of insulin, glucagon-like peptide-1, and appetite-stimulating hormone ghrelin, which impact lowering satiety response. (Welsh et al., 2013) A lower satiety response might increase calorie intake since young adults tend to have tight schedules that unconsciously force them to consume food/ beverage with quicker time consumption. Thus, they would prefer SSB as their calorie source than consuming food in solid form.

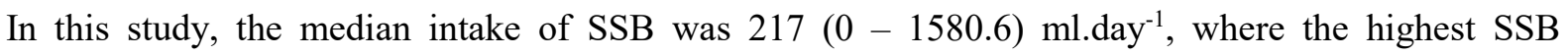
consumption came from sugar-sweetened milk-based drinks and sugar-sweetened tea drinks. This was lower than the previous finding by Guelinckx et al. in 2015, where the average beverage intake of

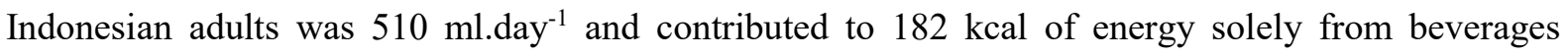
intake (Guelinckx et al., 2015). Guelinckx et al. (2015) described the highest fluid intake came from plain water (1.78 liters per day), hot beverages ( 0.26 liter per day), regular sweetened beverages $(0.17$ liter per day), milk, and derivates (0.05 liter per day), juices (20 milliliter per day), and other beverages (10 milliliters per day) (Guelinckx et al., 2015). 38.5\% of college students consumed sugarsweetened coffee every day, lower than a recent study by Mahoney et al. (2019) found that $92 \%$ of college students consumed caffeine in all forms (Mahoney et al., 2019). They consumed caffeine for 
keeping awake (79\%), enjoy the taste (68\%), social aspects (39\%), increase concentration (31\%), increase their physical energy (27\%), increasing mood (18\%), and releasing stress (9\%) (Mahoney et al., 2019).

Table 1 shows the added sugar intake solely from SSB was 23.4 grams per day or $7.5 \%$ of TEI. For obtaining the added sugar from SSB, this study focused on the total amount of added (extrinsic) sugar content in SSB, which was added during the preparation or at the table before drinking. Some respondents did not consume added sugar in SSB $\left(0\right.$ g.day $\left.{ }^{-1}\right)$. On the contrary, a respondent consumed added sugar 134.4 g.day $^{-1}$ from beverage only or almost tripled of Indonesian guideline. Compared to the recommendations from WHO and Indonesian guidelines, the added sugar intake was half of the Indonesian Guideline, where the calorie percentage almost reached WHO's strong recommendation (Kodyat, 2014, WHO, 2015). The finding of this study is higher than previous findings since the added sugar intake is solely from beverages intake. Total Diet Survey of Indonesia among the age 1955 years old in 2014 found average sugar intake was 16.4 grams per day, and the highest contribution came from sugar and confectionary (15.4 grams per day) (Kementerian Kesehatan, 2014). Sugar intakes consist of table sugar and its confectionary (table sugar, brown sugar, palm sugar), candy, syrup, and chocolate (chocolate powder and bar) (Kementerian Kesehatan, 2014). Thus, the researcher assumed that the maximum sugar intake from food should not exceed 26.6 g.day $^{-1}$ or $2.5 \%$ energy of TEI. This should be highlighted by stakeholders such as universities and public health parties to prevent the higher prevalence of overweight and obesity in young adults.

Table 1: Characteristic of respondents based on socio-demographic $(n=161)$

\begin{tabular}{|c|c|c|}
\hline Socio-demographic variables & n (\%) & Mean \pm SD or Median (Min-Max) \\
\hline Age (year) & & $19(19-21)$ \\
\hline \multicolumn{3}{|l|}{ Gender } \\
\hline Female & $93(57.8)$ & \\
\hline Male & $68(42.2)$ & \\
\hline \multicolumn{3}{|l|}{ Father's education level } \\
\hline Low (never or graduate JHS) & $47(29.2)$ & \\
\hline Moderate (graduate SHS) & $70(43.5)$ & \\
\hline High (graduate college/diploma) & $44(27.3)$ & \\
\hline \multicolumn{3}{|l|}{ Mother's education level } \\
\hline Low (never or graduate JHS) & $42(26.1)$ & \\
\hline Moderate (graduate SHS) & $72(44.7)$ & \\
\hline High (graduate college/diploma) & $47(29.2)$ & \\
\hline \multicolumn{3}{|l|}{ Father's occupation $(n=153)$} \\
\hline Non-government & $125(81.7)$ & \\
\hline Government & $28(18.3)$ & \\
\hline \multicolumn{3}{|l|}{ Mother's occupation ( $\mathrm{n}=155)$} \\
\hline Not working & $93(60.0)$ & \\
\hline Working & $62(40.0)$ & \\
\hline Total pocket money (IDR) $^{1}$ & & $1,587,577(500,000-7,500,000)$ \\
\hline Pocket money for food (IDR) & & $952,050(120,000-3,800,000)$ \\
\hline Parent's income (rupiah) $(\mathrm{n}=160)$ & & $3,000,000(500,000-40,000,000)$ \\
\hline Weight (kg) & & $53.9(33.7-111.8)$ \\
\hline Height $(\mathrm{cm})$ & & $159.9(143.8-178.6)$ \\
\hline Body mass index $\left(\mathrm{kg} \cdot \mathrm{m}^{-2}\right)$ & & $20.6(15.11-41.29)$ \\
\hline \multicolumn{3}{|l|}{ Nutritional Status } \\
\hline Underweight $\left(<18.5\right.$ kg.m $\left.{ }^{-2}\right)$ & & $30(18.6)$ \\
\hline
\end{tabular}


Normal $\left(18.5-22.9 \mathrm{~kg} \cdot \mathrm{m}^{-2}\right)$

Overweight and Obese $\left(\geq 23.0 \mathrm{~kg} \cdot \mathrm{m}^{-2}\right)$

SSB intake (ml.day $\left.{ }^{-1}\right)$

Added sugar in SSB (g.day $\left.{ }^{-1}\right)$

Energy from SSB (kcal. day $\left.{ }^{-1}\right)$

Calorie percentage from SSB (\%)

Total energy intake (kcal. day $\left.{ }^{-1}\right)$

Total energy intake

$<80 \%$ of RDA

$\geq 80 \%$ of RDA

$>100 \%$ of RDA

Physical activity level

Low $(<600$ MET)

Moderate-high ( $\geq 600$ MET)
$92(57.2)$

$39(24.2)$

$217.4(0-1580.6)$

$23.4(0-134.4)$

$126(0-626)$

$7.5(0-37.2)$

$1652(693-3489)$

JHS: Junior High School); SHS: Senior High School graduated; Father's occupation level: government (civil servant, police, army or state-owned corporation worker) and non-government; SSB: Sugar-sweetened beverage; RDA: Indonesian recommended dietary allowance/ Angka Kecukupan Gizi 2019; MET: metabolic equivalent; ${ }^{1} 1 \mathrm{USD}=14,398 \mathrm{IDR}$

In a previous study in 2015, according to "Description of Food Consumption, Nutritional Problems, and Non-Communicable Disease of Indonesia," the national sugar consumption of age more than 15 years old was 15.1 grams a day. There were $5.5 \%$ of that age that consumed more than 50 grams per day of daily sugar consumption (Kementerian Kesehatan, 2015). Surprisingly, this study found double prevalence $(11.8 \%)$ who consumed exceeding 50 grams per day solely from beverages, not included sugar intake from food. Based on the calorie percentage of SSB intake, 10.9\% of adults consumed sugar solely from SSB exceeding 10\% of TEI (Guelinckx et al., 2015), whereas, in this study, the percentage is tripled (36.6\%). Thus, the possibility of having health problems in advance caused by SSB intake is predicted to be higher than in 2015 .

The bivariate analysis did not find the association between BMI and socio-demographic factors. It was in contrast with the previous study that as people get older, they tend to have higher BMI (Hanandita and Tampubolon, 2015). They were categorized into 15-24, 25-34, 35-44, 45-54, 55-64, and +65 years old, and results showed that the 15-24 years old group was a reference (OR 1.000). The OR was increasing until 54 years old and decreasing afterward. The different result with that, this study found no association between body mass indexes with age. This difference might happen because this study participated smaller range of age, i.e., young adulthood (19-21 years old), than the previous one.

Table 2: Association between BMI and SSB consumption (compared to recommendations) ( $n=161$ )

\begin{tabular}{|c|c|c|c|}
\hline \multirow{2}{*}{ Variables } & \multicolumn{3}{|c|}{ BMI $\left(\mathrm{kg} \cdot \mathrm{m}^{-2}\right)$} \\
\hline & $\mathbf{r}$ & Median (Min-Max) & p value \\
\hline Added sugar consumption $^{1}$ & & & $0.159^{a}$ \\
\hline$<50$ g.day $^{-1}(\mathrm{n}=142)$ & & $20.6(15.1-41.3)$ & \\
\hline$\geq 50$ g.day $^{-1}(n=19)$ & & $21.6(16.6-41.2)$ & \\
\hline Gender & & & $0.119^{b}$ \\
\hline Male & & $20.75 \pm 3.99$ & \\
\hline Female & & $21.66 \pm 3.02$ & \\
\hline Physical activity level & & & $0.796^{\mathrm{b}}$ \\
\hline Low $(<600 \mathrm{MET})$ & & $21.32 \pm 3.44$ & \\
\hline Moderate-high ( $\geq 600 \mathrm{MET})$ & & $21.16 \pm 4.05$ & \\
\hline
\end{tabular}



Index among College Students Living in Dormitory

\begin{tabular}{lcc} 
Age (year) & -0.050 & $0.529^{\mathrm{c}}$ \\
Pocket money (rupiah) & 0.036 & $0.648^{\mathrm{c}}$ \\
Pocket money for food (rupiah) & 0.059 & $0.456^{\mathrm{c}}$ \\
Parent's income (rupiah) $(\mathrm{n}=160)$ & -0.014 & $0.857^{\mathrm{c}}$ \\
Total energy intake (kcal.day $\left.{ }^{-1}\right)$ & -0.018 & $0.821^{\mathrm{c}}$ \\
\hline
\end{tabular}

a: Mann-Whitney test; b: Independent T-Test; c: Spearmen Test;

${ }^{1}$ Added sugar intake recommendation from Ministry of Health of Indonesia (Kodyat, 2014); MET: metabolic equivalent

In this study, parents' education level, occupation level, and pocket money showed no association with the body mass index of college students. This was inconsistent with the previous study that those factors impact the body mass index of a person (Lee, 2017). One study stated that higher education levels affect higher BMI among underweight and lower BMI among overweight people (Römling and Qaim, 2011). This is expected since education may increase an individual's awareness and knowledge. No significant results may be caused by the living condition of respondents who lived in the dormitory. Their parents could not control their eating habits. A previous study mentioned that young adult who lives out of their parents' home tend to have unhealthy eating habits such as fast food, carbonated beverage, and alcohol consumption; as where are primary food decision-maker for food and beverages consumption (Bernardo et al., 2017).

In multiple analysis, SSB consumption and gender are significantly associated with BMI. Gender had a significant association due to the difference in biological factors between males and females.

Table 3: Multivariate analysis between SSB consumption (g.day ${ }^{-1}$ ) and BMI, adjusting for other potential factors

\begin{tabular}{|c|c|c|c|c|c|c|c|c|c|c|c|c|}
\hline \multirow[b]{2}{*}{ Variables } & \multicolumn{5}{|c|}{ Unadjusted } & \multicolumn{7}{|c|}{ Adjusted } \\
\hline & $\boldsymbol{\beta}$ & $95 \% \mathrm{C}$ & & $\begin{array}{c}\text { p- } \\
\text { value }\end{array}$ & $\mathbf{r}$ & $\mathbf{R}^{2}$ & $\boldsymbol{\beta}$ & $95 \%$ CI & & p-value & $\mathbf{R}$ & $\mathbf{R}^{2}$ \\
\hline Added sugar in & 1.75 & 0.013 & - & 0.048 & 0.156 & 0.024 & 1.810 & 0.014 & & $0.048^{*}$ & & \\
\hline $\begin{array}{l}\text { SSB } \\
\quad<50 \text { g.day }^{-1} \\
\quad \geq 50 \text { g.day }^{-1}\end{array}$ & 0 & 3.486 & & $*$ & & & & 3.606 & & & & \\
\hline $\begin{array}{l}\text { Gender } \\
\text { Male } \\
\text { Female }\end{array}$ & $\begin{array}{l}0.90 \\
5\end{array}$ & $\begin{array}{l}-0.234 \\
2.045\end{array}$ & - & 0.119 & 0.123 & 0.015 & 1.263 & $\begin{array}{l}0.067 \\
2.459\end{array}$ & - & $0.039 *$ & & \\
\hline $\begin{array}{l}\text { Physical activity } \\
\text { level } \\
\text { Moderate- } \\
\text { high } \\
\text { Low }\end{array}$ & $\begin{array}{l}0.16 \\
0\end{array}$ & $\begin{array}{l}-1.065 \\
1.386\end{array}$ & - & 0.796 & 0.020 & 0.000 & 0.020 & $\begin{array}{l}-1.203 \\
1.244\end{array}$ & - & 0.974 & 0.229 & 0.053 \\
\hline $\begin{array}{l}\text { Total energy } \\
\text { intake (kcal. day- } \\
\text { 1) }\end{array}$ & $\begin{array}{l}0.00 \\
1\end{array}$ & $\begin{array}{l}-0.001 \\
0.002\end{array}$ & - & 0.354 & 0.074 & 0.005 & 0.001 & $\begin{array}{l}-0.001 \\
0.002\end{array}$ & - & 0.325 & & \\
\hline Constant & & & & & & & $\begin{array}{c}18.106 \\
5 \\
\end{array}$ & $\begin{array}{r}14.468 \\
21.661 \\
\end{array}$ & - & $<0.001$ & & \\
\hline
\end{tabular}

*Significantly correlated; ENTER method; $p$-value in $\mathrm{ANOVA}=0.076 ; \mathrm{r}=0.229$

Dependent variable: BMI

Predictors: (constant) gender, added sugar (g.day ${ }^{-1}$ )

Females tend to have a fatter mass than males. Interaction between estrogen, leptin, and thyroid hormones in women would affect the energy expenditure to become lower, resulting in higher fat storage in women than men (Nurwanti et al., 2018). Metabolically, the body derives energy from 
carbohydrates broken down into monosaccharides such as glucose, galactose, and fructose and was absorbed in the intestinal system before being metabolized into energy. Sugars contained in SSB are mostly monosaccharides (glucose, galactose, and fructose) and disaccharides (sucrose, lactose, and maltose). Glucose and galactose were absorbed in intestinal cells into blood cells, while fructose was efficiently absorbed in the liver. When glucose and galactose are not used, those sugars would be stored as glycogen in muscle cells and adipose tissues, while fructose would be stored as glycogen and lactate in the liver. When energy is needed for physical activity, it will induce glycolysis for glucose synthesis, which eventually produced energy in the tricarboxylic acid (TCA) cycle (Gropper and Smith, 2012).

Similar to the previous finding in the US regarding the significant association between BMI and SSB intake, a $1 \%$ rise in soft drink consumption (US gallon) was associated with an additional 4.8 overweight adults per 100 (adjusted $\beta ; 95 \%$ confidence interval $[\mathrm{CI}]=3.1,6.5$ ) and 2.3 obese adults per $100(95 \% \mathrm{CI}=1.1,3.5)$, and 0.3 adults with diabetes per $100(95 \% \mathrm{CI}=0.1,0.8)$ (Basu et al., 2013). Another finding also found that people who consumed SSB had significantly higher BMI than non-consumer, which orange juice $(R R=1.282)$, sugar-sweetened fruit drinks $(R R=1.417)$, and soft drinks ( $R R=1.749)$ (Chan, 2011). The condition of young adults in this study had a high intake of SSB that may impact their BMI in their future life.

Another variable, such as health-related knowledge, might affect individuals' motivation and subsequently influence food and beverage choice. While, this study did not assess the knowledge, attitude practice related to health and nutrition. In further, it is necessary to conduct the intervention study to reduce consumption in young adults. According to Winpenny et al. in 2016, late adolescence to young adulthood is the transition period with high opportunities to form good dietary behavior; it's a good period to receive interventions (Winpenny et al., 2017). On another side, most young adults disregard building their long-term eating patterns, which affects their future life (Winpenny et al., 2017).

Respondents in this study were living away from home. One study in Saudi found that compared to college students living with families, students living in dormitory students have a higher risk of unhealthy dietary habits (Alghamdi et al., 2018). It might be due to their role as the primary decisionmaker for their food and beverage. They have the independence to spend their money on food and beverages. Supported by the dormitory canteen as the nearest food-beverage provider and campus cafeteria in all faculties may affect their SSB consumption. Study area, which is also surrounded by some big supermarket that provides fast-food restaurants supported by delivery order service, may increase their accessibility to consume more SSB. Meanwhile, in Canada, non-students and 2-year students tend to have poorer diets than 4-year college students (Nelson et al., 2009).

The respondents bought SSB in dormitory canteen, campus cafeteria, prepared by themselves, or delivery online, but mostly from beverages seller in dormitory canteen and self-making. In the dormitory canteen itself, the seller made a serving of SSB consist of sweetened condensed milk, table sugar (liquid form), and syrup. Sugar contended-wafer or -biscuit is added as an optional topping. The researcher assumed that the added sugar in one serving of SSB in the dormitory canteen contains high added sugar. This should become a warning to all stakeholders that sugar-sweetened beverages 
consumption was alarmingly high among college students living in the dormitory. If the current condition is not improved, it may lead to a higher risk of NCDs in the future. Health promotion, university regulation, and intervention studies could be conducted to reduce sugar-sweetened consumption among college students.

\section{Strengths and Limitations}

The author is aware that this study might have limitations instead of strengths. For assessing SSB consumption, the researcher used 7-days fluid record to assess the SSB consumption, which is more appropriate to assess fluid intake than 24-hour recall. It provided detailed information on SSB consumption and could capture all types of SSB, daily SSB intake (ml.day $\left.{ }^{-1}\right)$, added sugar content (g), energy intake (kcal), and calorie percentage of TEI (\% of TEI). However, since this study found overweight and obese young adults participated in the study, it cannot be denied there were dietary pattern changes to declining. The sampling method using convenience sampling made the results represent only students living in the dormitory.

This study has still had some limitations. However, the researcher has done some actions to minimize the error and bias in this study. This study excluded respondents who were reducing food and beverage intake to anticipate food and beverage intake bias. This study results provide the basic information or evidence regarding the current recommendation by the Ministry of Health of Indonesia that sugar intake should be less than $50 \mathrm{~g}$ or 4 tablespoons per day. This information may help some stakeholders to target the intervention for reducing SSB consumption.

\section{Conclusion}

In conclusion, respondents were young adults studying in the university with middle up socioeconomic status living in the dormitory. There were $24.2 \%$ of young adults having excess adiposity. As much as $11.8 \%$ consumed added sugar in SSB exceeded 50 g.day $^{-1}$, and $36.6 \%$ consumed calories more than WHO's strong recommendation solely from SSB. Significantly, the college students with added sugar in SSB more than 50 g.day ${ }^{-1}$ have higher BMI as $1.810 \mathrm{~kg} . \mathrm{m}-2$ than those who consumed less than 50 g.day ${ }^{-1}$.

\section{Recommendation}

Since the study found high SSB consumption among respondents and its impact on higher BMI in further life stages, it is necessary to conduct the intervention steps to reduce the SSB consumption. Considering the relatively high SSB consumption among university students might come from the food and beverage around campus area such as dormitory canteen, it is necessary to conduct socialization in terms of risk of SSB consumption and healthy hydration to all parties in the university such as students, staff and food and beverage providers and sellers. To minimize access to unhealthy diets, the university also needs to make a policy of a healthy campus cafeteria that should provide healthy food, including menu standards for making SSB.

It is necessary to conduct a cohort study to assess SSB consumption's effect on BMI among young adults. To understand the national situation of SSB consumption, further study should be conducted in 
a larger sample size to represent the young adult population stratified by gender, workplace, and living condition.

\section{References}

Alghamdi, E. S., Farrash, M. S., Bakarman, M. A. \& Mukhtar, A. M. 2018. Dietary Habits of University Students Living at Home or University Dorm: A Cross-Sectional Study in Saudi Arabia. Global Journal of Health Science, 10.

Andersen, L. F., Lillegaard, I. T. L., Øverby, N., Lytle, L., Klepp, K.-I. \& Johansson, L. 2005. Overweight and obesity among Norwegian schoolchildren: changes from 1993 to 2000. Scandinavian journal of public health, 33, 99-106.

Anderson, A. S. \& Good, D. J. 2017. Increased body weight affects academic performance in university students. Preventive medicine reports, 5, 220-223.

Badan Penelitian Dan Pengembangan Kesehatan, K. K. R. 2018. Hasil Utama Riskesdas 2018.

Bandini, L. G., VU, D., Must, A., Cyr, H., Goldberg, A. \& Dietz, W. H. 1999. Comparison of high-calorie, low-nutrient-dense food consumption among obese and non-obese adolescents. Obesity Research, 7, 438-443.

Bardosono, S., Monrozier, R., Permadhi, I., Manikam, N. R. M., Pohan, R. \& Guelinckx, I. 2015. Total fluid intake assessed with a 7-day fluid record versus a 24-h dietary recall: A crossover study in Indonesian adolescents and adults. European journal of nutrition, 54, 17-25.

Basu, S., Mckee, M., Galea, G. \& Stuckler, D. 2013. Relationship of soft drink consumption to global overweight, obesity, and diabetes: A cross-national analysis of 75 countries. American journal of public health, 103, 2071-2077.

Bernardo, G. L., Jomori, M. M., Fernandes, A. C. \& Proença, R. P. D. C. 2017. Food intake of university students. Revista de Nutrição, 30, 847-865.

Boričić, K., Simić, S., Vasiljević, N. \& Marinković, J. 2014. Risk Factors Associated with Overweight among Adolescents in Serbia/Dejavniki Tveganja, Povezani S Prekomerno Telesno Težo Pri Mladostnikih V Srbiji. Slovenian Journal of Public Health, 53, 283-293.

Bouchard, D. R., Ross, R. \& Janssen, I. 2010. Coffee, tea and their additives: Association with BMI and waist circumference. Obesity Facts, 3, 345-352.

Chan, T. 2011. Sugar-Sweetened Beverage Consumption Frequency vs. BMI: National Health and Nutrition Examination Survey 2003-2004.

Gropper, S. S. \& Smith, J. L. 2012. Advanced nutrition and human metabolism, Cengage Learning.

Guelinckx, I., Ferreira-Pêgo, C., Moreno, L., Kavouras, S., Gandy, J., Martinez, H., Bardosono, S., Abdollahi, M., Nasseri, E. \& Jarosz, A. 2015. Intake of water and different beverages in adults across 13 countries. European journal of nutrition, 54, 45-55.

Hanandita, W. \& Tampubolon, G. 2015. The double burden of malnutrition in Indonesia: Social determinants and geographical variations. SSM-population health, 1, 16-25.

Haning, M. T., Arundhana, A. I. \& Muqni, A. D. 2016. The government policy related to sugar-sweetened beverages in Indonesia. Indian Journal of Community Health, 28, 222-227.

Harbuwono, D. S., Pramono, L. A., Yunir, E. \& Subekti, I. 2018. Obesity and central obesity in Indonesia: Evidence from a national health survey. Medical Journal of Indonesia, 27, 114-20.

Jensen, B. W., Nichols, M., Allender, S., De Silva-Sanigorski, A., Millar, L., Kremer, P., Lacy, K. \& Swinburn, B. 2013. Inconsistent associations between sweet drink intake and 2-year change in BMI among Victorian children and adolescents. Pediatric obesity, 8, 271-283.

Johnson, R. K., Appel, L. J., Brands, M., Howard, B. V., Lefevre, M., Lustig, R. H., Sacks, F., Steffen, L. M. \& Wylie-Rosett, J. 2009. Dietary sugars intake and cardiovascular health: A scientific statement from the American Heart Association. Circulation, 120, 1011-1020.

Kementerian Kesehatan, R. 2014. Buku Studi Diet Total 2014. 
Kementerian Kesehatan, R. 2015. Gambaran Konsumsi pangan, Permasalahan Gizi, dan Penyakit Tidak Menular. Jakarta.

Kementerian Kesehatan, R. 2018. Riskesdas 2018 .

Kodyat, B. A. 2014. Pedoman Gizi Seimbang 2014. Permenkes RI, 41.

Lanoye, A., Gorin, A. A. \& Larose, J. G. 2016. Young adults' attitudes and perceptions of obesity and weight management: Implications for treatment development. Current obesity reports, 5, 14-22.

Lee, Y. 2017. Slender women and overweight men: Gender differences in the educational gradient in body weight in South Korea. International journal for equity in health, 16, 202.

Mahoney, C. R., Giles, G. E., Marriott, B. P., Judelson, D. A., Glickman, E. L., Geiselman, P. J. \& Lieberman, H. R. 2019. Intake of caffeine from all sources and reasons for use by college students. Clinical Nutrition, 38, 668-675.

Mattes, R. D. 1996. Dietary compensation by humans for supplemental energy provided as ethanol or carbohydrate in fluids. Physiology \& behavior, 59, 179-187.

Metwally, M., LI, T. \& Ledger, W. 2007. The impact of obesity on female reproductive function. Obesity Reviews, 8, 515-523.

Nelson, M. C., Larson, N. I., Barr-Anderson, D., Neumark-Sztainer, D. \& Story, M. 2009. Disparities in dietary intake, meal patterning, and home food environments among young adult nonstudents and 2-and 4-year college students. American Journal of Public Health, 99, 1216-1219.

Nurwanti, E., Uddin, M., Chang, J.-S., Hadi, H., Syed-Abdul, S., SU, E., Nursetyo, A., Masud, J. \& Bai, C.-H. 2018. Roles of sedentary behaviors and unhealthy foods in increasing the obesity risk in adult men and women: A cross-sectional national study. Nutrients, 10, 704.

Peltzer, K., Pengpid, S., Samuels, T., Özcan, N., Mantilla, C., Rahamefy, O., Wong, M. \& Gasparishvili, A. 2014. Prevalence of overweight/obesity and its associated factors among university students from 22 countries. International journal of environmental research and public health, 11, 7425-7441.

Pengpid, S. \& Peltzer, K. 2017. The Prevalence of Underweight, Overweight/Obesity and Their Related Lifestyle Factors in Indonesia, 2014-2015. AIMS public health, 4, 633.

Poobalan, A. \& Aucott, L. 2016. Obesity among young adults in developing countries: A systematic overview. Current obesity reports, 5, 2-13.

Riskesdas 2013. Riskesdas 2013. Jakarta: Kementerian Kesehatan RI.

Römling, C. \& Qaim, M. 2011. Direct and indirect determinants of obesity: The case of Indonesia.

Sahoo, K., Sahoo, B., Choudhury, A. K., Sofi, N. Y., Kumar, R. \& Bhadoria, A. S. 2015. Childhood obesity: Causes and consequences. Journal of Family Medicine and Primary Care, 4, 187-192.

Sparling, P. B. 2007. Obesity on campus. Preventing chronic disease, 4.

Wang, H., Steffen, L. M., Zhou, X., Harnack, L. \& Luepker, R. V. 2013. Consistency between increasing trends in added-sugar intake and body mass index among adults: The Minnesota Heart Survey, 1980-1982 to 20072009. American journal of public health, 103, 501-507.

Welsh, J. A., Lundeen, E. A. \& Stein, A. D. 2013. The sugar-sweetened beverage wars: Public health and the role of the beverage industry. Current opinion in endocrinology, diabetes, and obesity, 20, 401.

WHO 2000. The Asia-Pacific perspective: Redefining obesity and its treatment.

WHO 2015. Guideline: sugars intake for adults and children, World Health Organization.

WHO 2016. Global health estimates 2016: Deaths by cause, age, sex, by country and by region, 2000-2016. World Health Organization.

WHO 2017. Prevalence of overweight among adults, BMI $\geq 25$, age-standardized estimates by WHO Region. WHO. URL: https://apps. who. int/gho/data/view. main. GLOBAL2461A.

Winpenny, E. M., Penney, T., Corder, K., White, M. \& Van Sluijs, E. 2017. Changes in consumption of added sugars from age 13 to 30 years: A systematic review and meta-analysis of longitudinal studies. Obesity Reviews, 18, 1336-1349. 